\title{
THE MODEL OF FORMING COMPETITIVE STRATEGY OF AN ENTERPRISE UNDER THE CONDITIONS OF OLIGOPOLIC MARKET
}

\author{
Romualdas Ginevičius ${ }^{1}$, Algirdas Krivka² ${ }^{2}$ Jolita Šimkūnaitè ${ }^{3}$ \\ 1,2,3 Department of Economics and Management of Enterprises, Vilnius Gediminas Technical \\ University, Sauletekio al. 11, 10223 Vilnius, Lithuania \\ E-mails: ${ }^{1}$ romualdas.ginevicius@vgtu.lt; ${ }^{2}$ akrivka@gmail.com; ${ }^{3}$ jolita.šimkunaite@gmail.com
}

Received 20 August 2009; accepted 15 June 2010

\begin{abstract}
The article presents the original and scientifically brand new model of forming the integrated competitive strategy of an enterprise under the conditions of oligopolic market, followed by the cases of empirical application. The integrated competitive strategy of oligopolic enterprise is considered to be the concerted set of partial (detailed) competitive strategies targeting the certain elements of internal and external environment of an enterprise, determining its strategic position and influencing performance. The complex assessment of the estimated impact of partial competitive strategies on performance criteria is implemented (multicriteria evaluation methods are applied) in order to indicate the detailed strategies, having the highest potential influence on enterprise performance (to be selected to form the integrated competitive strategy), and to determine their scales (weights in the structure of the integrated strategy). The results of empirical application of the model are proposed to be employed to set up long-term goals and choose the main directions of business strategy of an enterprise, to distribute financial, human and other resources for strategic actions to be designed and implemented.
\end{abstract}

Keywords: competitive strategy, oligopolic market, model, multicriteria evaluation, SAW, TOPSIS, VIKOR.

Reference to this paper should be made as follows: Ginevičius, R.; Krivka, A.; Šimkūnaitè, J. 2010. The model of forming competitive strategy of an enterprise under the conditions of oligopolic market, Journal of Business Economics and Management 11(3): 367-395.

\section{Introduction}

Business strategy is a response to rapidly changing, hardly forecasted environment of an enterprise; moreover, it is considered to be a proper tool to affect the environment in a favourable manner in order to achieve the performance meeting the expectations of business owners. Theoretical sources of strategic management distinguish between the two main levels of business strategy: corporate and competitive. The former is related to large, diversified companies and includes the strategic actions of operating a portfolio of business units (entering a new market, withdrawing from a market, distributing resources among business units); the latter encompasses the strategic actions of a business unit or of a non-diversified enterprise to capture the strategic position, achieve and 
maintain long-term competitive advantage seeking for favourable financial performance in the certain market or industry.

Competitive strategy is aimed at achieving long-term competitive advantage due to superior, compared to competitors, strategic position in the market (Porter 1979, 1998a, 1998b) or unique, valuable, non-mobile resources and capabilities (Prahalad and Hamel 1990; Peteraf 1993; Grant 1991, 1996; Barney 1991; Teece et al. 1997). Modern theoretical models of analyzing enterprise's competitive potential and forming business strategy, coupled by empirical research of that kind, are dominated by the balanced view of enterprise's environment affecting business strategy (Ginevičius 2000; Ginevičius and Podvezko 2004; Raudeliūnienè 2007; Bivainis and Staškevičius 2004; Korsakienė 2004; David 2007); although, some of them rely on resource advantages or market positioning only (Časas 2000; Sekliuckienè 2006).

Scientific sources of strategic management propose a wide range of variously classified business strategies, with their application depending on objectives and strategic position of an enterprise: M. Porter's cost leadership, differentiation and focus generic strategies, I. Ansoff's growth strategies, strategies of vertical integration and diversification, offensive and defensive strategies, strategies implemented during specific stages of industry evolution (growth, maturity, decline), strategies depending on enterprise's relative position in the market (leader, challenger, follower, nicher), etc (Porter 1998a, 1998b; Ansoff 1984; Thompson et al. 2005; David 2007; Kotler and Keller 2006; Ginevičius 1998, 2009; Raudeliūnienè 2007).

Generic (universal) business strategies, developed by the scholars of strategic management, together with the analyzed models of exploring enterprise strategic behaviour, proposed by the other authors, are not related to the specific market or industry structure. The choice of oligopoly as the market structure under research is motivated by its common occurrence and considerable relative scale in Lithuanian economy (Ginevičius and Krivka 2009b), complicated and ambiguous strategic conduct of oligopolic enterprises, coupled by potential inefficiency of oligopolic market structure (Ginevičius and Krivka 2008a, 2008b; Krivka and Ginevičius 2009). Strategic decisions of oligopolic enterprises might be simulated by applying game theory models: cartels and other agreements on coordination of actions, the first and the second mover advantage, competition of prices or quantities produced, entrance deterrence (Von Neumann and Morgenstern 1953; Friedman 1969, 1971, 1988; Ginevičius and Krivka 2008a; Raguseo 2009).

The scientific problem raised in the article is developing the complex model of enterprise competitive strategy under the conditions of oligopolic market, based on theoretical concepts of strategic management and modern methods of quantitative evaluation, affording ground for forming the competitive strategy that achieves goals and expected performance of an enterprise.

The aim of the research is to design and apply in practice the original, scientifically grounded model of forming the integrated competitive strategy of oligopolic enterprise, enabling to assess the strategic alternatives to be implemented and form the competitive strategy meeting the expectations of business owners. 


\section{The model}

The model of forming the integrated competitive strategy of oligopolic enterprise is designed in three steps: with regard to performed scientific literature analysis (references are given in the introduction) the set of partial competitive strategies (the elements of the integrated strategy) is generated, the system of enterprise performance indicators (partial strategies' evaluation criteria) is designed, and the methodology for quantitative assessment of partial strategies is proposed.

\subsection{Partial competitive strategies of oligopolic enterprise}

The integrated competitive strategy of oligopolic enterprise is considered to be a concerted set of partial (detailed) competitive strategies, targeting the certain elements of internal and external environment of an enterprise, determining its strategic position and influencing performance. The analysis of strategic conduct in the context of the integrated strategy, on one hand, reflects the conditions of oligopolic market, where enterprise's reaction to changing environment involves a wide range of factors, having considerable impact on its strategic position and performance, with no single strategy able to affect all the relevant elements of environment; on the other hand, a simplified and forthright strategy would soon be identified by competitors, and their response would diminish the results of strategy application. Eighteen partial competitive strategies are proposed to be included in the model of forming the integrated competitive strategy of oligopolic enterprise:

1. Market expansion strategies (bringing new customers to join the market, widening the range of purposes and occasions for consumption).

2. Entrance deterrence strategies.

3. Strategies targeting market segments (creating new market segments, seeking for leadership in the specific segment).

4. Marketing and promotion strategies (creating and maintaining brand names, advertising and other promotion measures, design and packing of the product).

5. Product development strategies (modification and improvement of goods or services, designing product batches).

6. Strategies aimed at creating the contingent of permanent customers (stimulating customer loyalty, increasing switching costs, improving after-sale service).

7. Strategies targeting suppliers (diversification of supply, forming and maintaining long-term relations with reliable suppliers, backward vertical integration or diversification).

8. Strategies targeting distribution channels (diversification of distribution, forming and maintaining long-term relations with reliable distributions channels, forward vertical integration or diversification).

9. Strategies targeting complements of the product (cooperation with producers of complements, diversification into complements' markets).

10. Strategies of developing and maintaining human and managerial resources.

11. Strategies of developing and maintaining technological resources. 
12. Strategies of developing and maintaining information systems.

13. Strategies aimed at gaining and maintaining a good name and reputation of the enterprise.

14. Offensive strategies (price war and other forms of savage competition).

15. Defensive strategies (defending market share, offence deterrence).

16. Response strategies.

17. Collaboration and cooperation strategies.

18. Follower strategies (imitation of competitors' goods or services, repeating the actions of successful competitors, following competitors' pricing).

Partial competitive strategies comprise the unique integrated competitive strategy of oligopolic enterprise with its exclusiveness (and barriers protecting from imitation) based on two dimensions: the set of the partial strategies implemented, and the scale of each partial strategy (their relative weights in the structure of the integrated strategy). Partial competitive strategies are selected and their scales are determined with regard to their expected contribution to enterprise financial performance.

\subsection{Enterprise performance indicators}

Enterprise performance is defined by the summarised financial indicator, comprised of detailed performance indicators, directly affected by partial strategies. To select the performance criteria, traditional profit-loss analysis is assumed (Juozaitienè 2007; Gronskas 2005), while the integrated performance indicator is decomposed into the following detailed indicators, characterising enterprise's residual demand, its revenues from one unit of sales and costs to one litas of sales:

1. The number of newly attracted customers indicates the results of enterprise's competitive activities attracting new consumers that join the market, or taking over competitors' clients.

2. The number of customers lost shows enterprise's abilities to stimulate customer loyalty and repeated consumption, to defend from competitors' actions aimed at taking over own clients.

3. Intensity of consumption indicates how often customers purchase and consume enterprise's goods or services.

4. Material value of goods or services reflects the utility gained from material features of goods or services consumed.

5. Consumer-realised non-material value of goods or services is considered to be additional customer satisfaction from goods or services, for which she is willing to pay more than assumed material value: the prestige of a brand name or producer, correspondence to fashion trends or individual preferences, etc.

6. Flexible pricing and price discrimination indicates enterprise's abilities to set the prices of goods or services freely (independent from other entities involved: competitors, distribution channels, government) and flexibly; also the capabilities to differentiate goods or services according to value and price dimensions with regard to customer needs and paying ability.

7. Costs of sales to one litas of sales indicate the costs of producing or purchasing 
(to resell) goods or services and depend on enterprise's internal resources and capabilities, accompanied by its relations with suppliers.

8. Distribution costs to one litas of sales depend on enterprise's resources and capabilities in case it sells goods or services itself, or on its relations with distribution channels.

9. General and administration costs to one litas of sales reflect the efficiency of enterprise management, enterprise size and the effect of scale economy, the abilities of controlling fixed costs.

The first three detailed indicators determine enterprise sales in units of goods or the number of its clients, indicators 4 to 6 directly influence the prices of goods or services set - all together, the subsystem of indicators 1 to 6 determines enterprise revenues from selling goods or services. The remaining indicators are associated with costs of producing and selling goods (providing services) - with their inclusion in the model, the summarised (integrated) enterprise performance criterion is considered to be the ultimate financial result, i.e. profit or loss.

\subsection{Quantitative assessment of partial competitive strategies}

The purpose of the quantitative assessment is, by applying appropriate mathematical methods, to determine the set of favourable detailed strategies to comprise enterprise's integrated competitive strategy, and to estimate the scales of the partial strategies chosen. The corresponding mathematical problem involves the assessment of partial competitive strategies with regard to their influence on the detailed performance indicators to solve a problem of that kind, multicriteria evaluation methods, developed throughout the recent years and widely applied in construction (e.g. Zavadskas et al. 1998, 2001, 2008, 2010; Ginevičius et al. 2008b), economics and management (e.g. Ginevičius et al. 2005, 2008a; Ginevičius and Podvezko 2004, 2006, 2008b, c, 2009; Ginevičius and Zubrecovas 2009; Ginevičius and Krivka 2009a; Bivainis and Zinkevičiūtė 2006), seem to be the appropriate tool.

The alternatives under evaluation are the partial competitive strategies, selected to be implemented by the enterprise - each of them is assessed with regard to the impact on the detailed performance indicators (Table 1).

The expected impact of the partial competitive strategy $j(j=1, \ldots, n)$ on the detailed performance indicator $i(i=1, \ldots, m)$ is measured by points: ranging from -3 to 3 , depending on the direction and the strength of the effect: $1 /-1-$ positive and negative weak impact respectively, $2 /-2$ - medium-strength impact, 3/-3 - strong impact, 0 neutral impact. The coefficients of potential influence of enterprise's internal and external environment on the application of each partial strategy are estimated as follows: 2 - environment is favourable for implementing the strategy, 1 - environment is neutral, 0.5 - environment is unfavourable.

The positive values (from 1 to 3 ) of partial strategies' impact on performance criteria are multiplied by the coefficients above, while the negative values are divided: it is assumed that favourable environment strengthens the positive effect of the implemented 
R. Ginevičius, A. Krivka, J. Šimkünaite. The model of forming competitive strategy of an enterprise...

\begin{tabular}{|c|c|c|c|c|c|c|c|c|c|c|c|}
\hline & 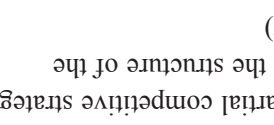 & 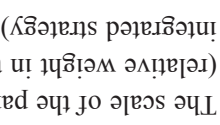 & $\omega^{-1}$ & $\omega^{2}$ & $\vdots$ & $\vdots$ & $\vdots$ & $\vdots$ & $\vdots$ & $\vdots$ & $\dot{s}$ \\
\hline & 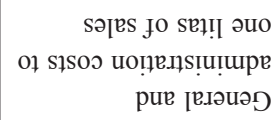 & $a$ & 2 & 2 & $\vdots$ & $\vdots$ & $\vdots$ & $\vdots$ & $\vdots$ & $\vdots$ & 2 \\
\hline & $\begin{array}{l}\text { sə[es Jo seł! əuo } \\
\text { oł słsor uọ̣nqțlı! }\end{array}$ & I $\infty$ & $2 \infty$ & $\vdots$ & & & & & & & $\vdots$ \\
\hline 苞 & 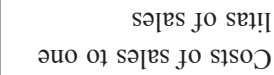 & I & $\vdots$ & & & & & & & & $\vdots$ \\
\hline 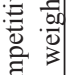 & 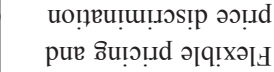 & 6 & $\vdots$ & & & & & & & & $\vdots$ \\
\hline 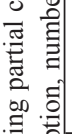 & 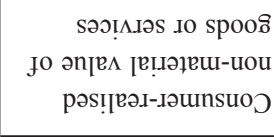 & $\ln$ & $\therefore$ & $\vdots$ & $\vdots$ & $\vdots$ & $\vdots$ & $\vdots$ & $\vdots$ & $\vdots$ & $\therefore$ \\
\hline $\begin{array}{ll}0 & 0 \\
0 & 0 \\
0 & 0 \\
z & 0 \\
& 0 \\
0\end{array}$ & 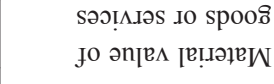 & +4 & $\vdots$ & & & & & & & & $\vdots$ \\
\hline 造 & $\begin{array}{l}\text { uo!̣dunsuos } \\
\text { Jo Kł!̣suəłuI }\end{array}$ & $m$ & $\vdots$ & & & & & & & & $\vdots$ \\
\hline & 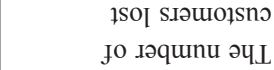 & $\sim$ & in & $\vdots$ & & & & & & & $\vdots$ \\
\hline & 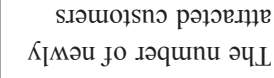 & $3^{-1}$ & $=$ & $\stackrel{2}{-1}$ & $\vdots$ & $\vdots$ & $\vdots$ & $\vdots$ & $\vdots$ & $\vdots$ & 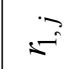 \\
\hline & & [x.ınวu & & & & & & & & & \\
\hline & 苞 & 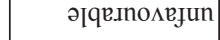 & & & & & & & & & \\
\hline $\begin{array}{ll}\Xi & 0 \\
\Xi & 0\end{array}$ & & әqе.Inо $\Lambda \mathcal{E}_{\mathrm{J}}$ & & & & & & & & & \\
\hline 部 & & [в.дnәu & & & & & & & & & \\
\hline & 苞 声 & әү૧в.пnомв]นи & & & & & & & & & \\
\hline & & 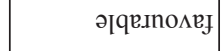 & & & & & & & & & \\
\hline & 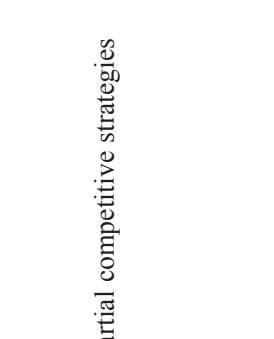 & 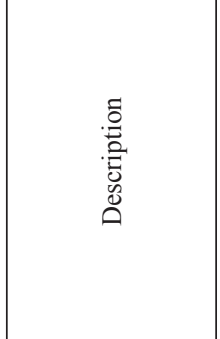 & 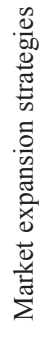 & 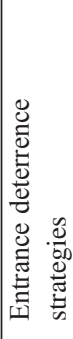 & 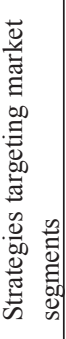 & 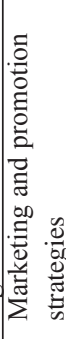 & 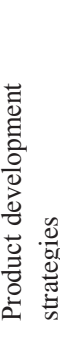 & 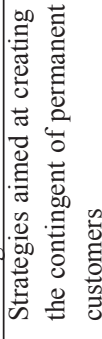 & 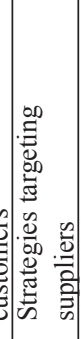 & 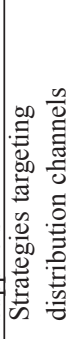 & 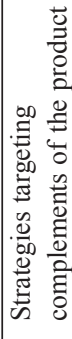 \\
\hline & & z & -1 & N & $m$ & $\nabla$ & in & 0 & r & $\infty$ & $a$ \\
\hline
\end{tabular}




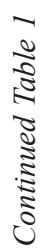

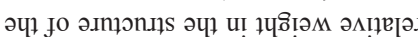

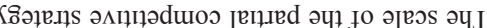

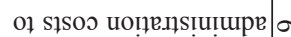

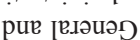

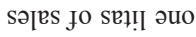

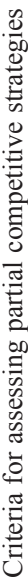

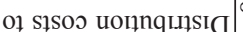

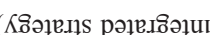
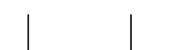

\begin{tabular}{|c|c|c|c|c|c|c|c|c|c|c|}
\hline \multirow{9}{*}{ 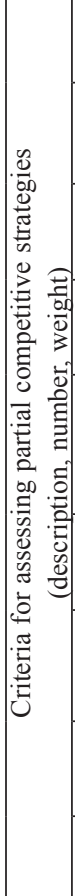 } & 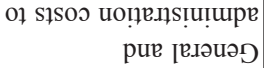 & 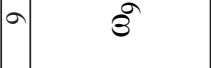 & $\vdots$ & $\vdots$ & $\vdots$ & $\vdots$ & & & $\therefore \vec{a}$ & $\leqslant \vec{a}$ \\
\hline & 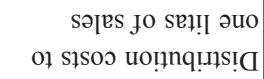 & $3^{\infty}$ & & & & & & & $\vdots$ & $\stackrel{\infty}{\infty}$ \\
\hline & $\begin{array}{l}\text { səjes jo seł!l } \\
\text { əuo oł səjes jo słsoつ }\end{array}$ & $\hat{3}$ & & & & & & & & $\vdots$ \\
\hline & 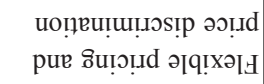 & $3^{0}$ & & & & & & & & $\vdots$ \\
\hline & 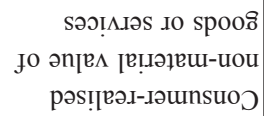 & $3^{n}$ & $\vdots$ & $\vdots$ & $\vdots$ & $\vdots$ & & & $\vdots$ & $\stackrel{\infty}{=}$ \\
\hline & 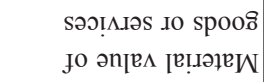 & $3^{+}$ & & & & & & & & $\vdots$ \\
\hline & 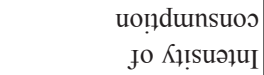 & $3^{m}$ & & & & & & & & $\vdots$ \\
\hline & 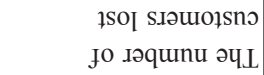 & $\mathfrak{\Im}^{N}$ & & & & & & & $\vdots$ & $\stackrel{\infty}{2}$ \\
\hline & 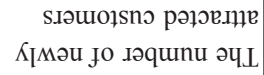 & $3^{-1}$ & $\vdots$ & $\vdots$ & $\vdots$ & $\vdots$ & & & 프 & $\stackrel{2}{\infty}$ \\
\hline \multirow{6}{*}{ 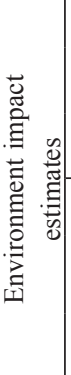 } & \multirow{3}{*}{ 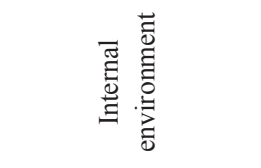 } & [e.ฺnวu & & & & & & & & \\
\hline & & ә૧qв..nо & & & & & & & & \\
\hline & & ә૧૯.Ino $\Lambda \mathrm{e}_{\mathrm{J}}$ & & & & & & & & \\
\hline & \multirow{3}{*}{ 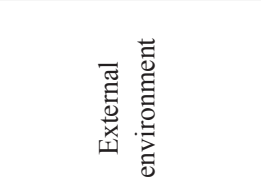 } & [ย.ınว & & & & & & & & \\
\hline & & ә૧qв..nо & & & & & & & & \\
\hline & & ә૧с.Inо $\Lambda \varepsilon_{\mathcal{J}}$ & & & & & & & & \\
\hline \multirow{2}{*}{\multicolumn{2}{|c|}{ 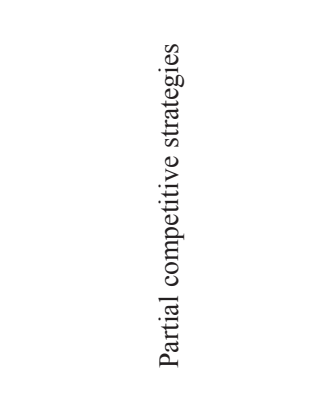 }} & 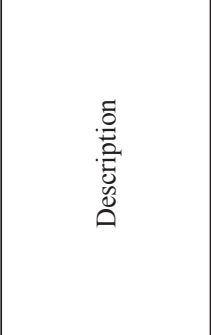 & 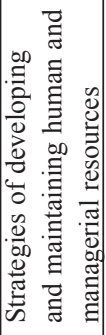 & 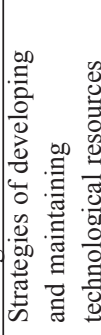 & 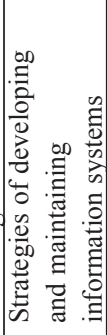 & 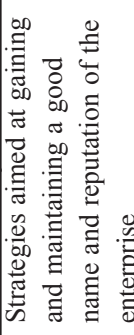 & 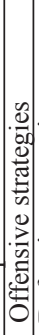 & 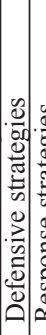 & 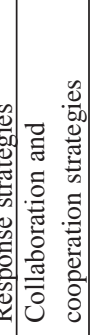 & 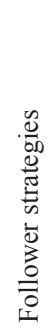 \\
\hline & & $\stackrel{\circ}{\mathrm{z}}$ & $\stackrel{ }{ }$ & $\exists$ & $\stackrel{\sim}{\sim}$ & 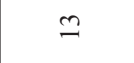 & \pm & $\approx$ & 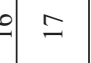 & 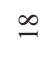 \\
\hline
\end{tabular}


strategy and weakens the negative effect, and vice-versa. To estimate weights $\omega_{i}$ of the performance indicators, the method of direct expert evaluation is applied, with respect to condition $\sum_{i=1}^{m} \omega_{i}=1$ (Ginevičius et al. 2005, 2008a; Ginevičius and Podvezko 2008b). The result of multicriteria evaluation is the ranking of strategic alternatives, enabling to form the integrated competitive strategy and estimate the scale $s_{j}$ of each partial strategy chosen, i.e. their relative weights in the structure of the integrated strategy.

The experience of recent research (e.g. Ginevičius and Podvezko 2008b, 2009; Ginevičius et al. 2008a, 2008b; Ginevičius and Zubrecovas 2009; Ginevičius and Krivka 2009a) suggests that the phenomenon under analysis is to be assessed by applying several multicriteria methods seeking for higher reliability of results; moreover, in order to minimize the subjectivity of the specific method, the average ranks are accepted to be the ultimate result. To efficiently combine several multicriteria evaluation methods, it is important to form a "bunch" of correlating methods (Ginevičius and Podvezko 2008a). SAW, TOPSIS and VIKOR methods are selected for the assessment of partial competitive strategies, refusing three other widely applied multicriteria techniques: Sum of Ranks and Geometric Average are rejected because of ignoring weights of criteria (that would distort the results of evaluation); COPRAS is inappropriate because all the criteria are assumed to be maximizing.

SAW method calculates the sum $S_{j}$ of normalized weighted values $\tilde{r}_{i j}$ of all criteria for each $j$-th alternative (Ginevičius et al. 2005, 2008a, 2008b; Ginevičius and Podvezko 2008c):

$$
S_{j}=\sum_{i=1}^{m} \omega_{i} \tilde{r}_{i j}
$$

TOPSIS indicates the best and the worst solutions with regard to each criteria (Opricovic and Tzeng 2004; Ginevičius et al. 2008a, 2008b; Ginevičius and Podvezko 2006, 2008b, 2009; Ginevičius 2008):

$$
\begin{aligned}
& V^{*}=\left\{V_{1}^{*}, V_{2}^{*}, \ldots, V_{m}^{*}\right\}=\left\{\left(\max _{j} \omega_{i} \tilde{r}_{i j} / i \in I_{1}\right),\left(\min _{j} \omega_{i} \tilde{r}_{i j} / i \in I_{2}\right)\right\}, \\
& V^{-}=\left\{V_{1}^{-}, V_{2}^{-}, \ldots, V_{m}^{-}\right\}=\left\{\left(\min _{j} \omega_{i} \tilde{r}_{i j} / i \in I_{1}\right),\left(\max _{j} \omega_{i} \tilde{r}_{i j} / i \in I_{2}\right)\right\},
\end{aligned}
$$

where: $I_{1}$ is a set of maximizing criteria, $I_{2}$ is a set of minimizing criteria, $\tilde{r}_{i j}$ is a normalized value of $i$-th criterion for $j$-th object. The distance of each alternative to the best and the worst solutions is calculated:

$$
D_{j}^{*}=\sqrt{\sum_{i=1}^{m}\left(\omega_{i} \tilde{r}_{i j}-V_{i}^{*}\right)^{2}}
$$




$$
D_{j}^{-}=\sqrt{\sum_{i=1}^{m}\left(\omega_{i} \tilde{r}_{i j}-V_{i}^{-}\right)^{2}},
$$

followed by the TOPSIS criterion, which maximum value corresponds to the best alternative:

$$
C_{j}^{*}=\frac{D_{j}^{-}}{D_{j}^{*}+D_{j}^{-}} .
$$

VIKOR is based on three evaluation criteria $S_{j}, R_{j}$ and $Q_{j}$, calculated by the following formulas (Opricovic and Tzeng 2004; Ginevičius et al. 2008a, 2008b; Ginevičius and Podvezko 2006, 2008b; Ginevičius 2008):

$$
\begin{gathered}
S_{j}=\sum_{i=1}^{m} \omega_{i} \tilde{r}_{i j}, \\
R_{j}=\max _{i}\left(\omega_{i} \tilde{r}_{i j}\right), \\
Q_{j}=v \frac{S_{j}-S^{*}}{S^{-}-S^{*}}+(1-v) \frac{R_{j}-R^{*}}{R^{-}-R^{*}},
\end{gathered}
$$

where: $\tilde{r}_{i j}$ is a normalized value of $i$-th criterion for $j$-th object, $S^{*}=\min _{j} S_{j}, S^{-}=\max _{j} S_{j}$ $R^{*}=\min _{j} R_{j}, R^{-}=\max _{j} R_{j}, v$ is the majority criterion, equalled to 0.5 in empirical research (e.g. Ginevičius et al. 2008a; Ginevičius and Krivka 2009a). The lowest values of $Q_{j}$ indicate the best alternatives.

Where negative values are involved in multicriteria assessment, they are transformed to positive by applying the shifting constant $b_{i}$ to each $i$-th criterion having at least one negative $r_{i j}$ value (Ginevičius and Čirba 2005; Podvezko 2008):

$$
\bar{r}_{i j}=r_{i j}+b_{i} .
$$

For the shifting procedure to have the least possible effect on evaluation results, the minimum values of the shifting constant are considered, calculated as follows:

$$
b_{i}=\left|\min _{j} r_{i j}\right|+0.001 .
$$

\section{Empirical application of the model}

The designed model of forming the integrated competitive strategy is applied to three enterprises operating in different oligopolic markets: enterprise A, enterprise B and 
enterprise C. The questionnaires, submitted to the enterprises under research, apply for the following data:

1) by the method of direct evaluation to estimate weights of the detailed performance indicators (evaluation criteria);

2) to choose the partial competitive strategies the enterprise intends to implement (potentially beneficial strategic alternatives) from the list of eighteen partial strategies assumed in the model;

3 ) to estimate the impact of enterprise's internal and external environment on application of each partial strategy chosen (favourable, unfavourable, neutral);

4) to estimate the expected impact of each partial strategy chosen on the detailed performance indicators (positive or negative weak, medium-strength, strong or neutral).

The questionnaires for estimating weights of the performance indicators were additionally submitted to 35 enterprises, acting in oligopolic markets. Five answers were received, making the total number of eight experts to have estimated weights of the evaluation criteria (together with enterprises A, B and C, Table 2).

Table 2. Expert estimates of evaluation criteria weights

\begin{tabular}{c|l|c|c|c|c|c|c|c|c|c}
\hline \multicolumn{1}{l|}{$\begin{array}{l}\text { Evaluation criteria } \\
\text { (performance indicators) }\end{array}$} & \multicolumn{7}{c}{ Experts and their estimates } \\
\hline No & \multicolumn{1}{|c|}{ Description } & 1 & 2 & 3 & 4 & 5 & 6 & 7 & 8 & Averages \\
\hline 1 & $\begin{array}{l}\text { The number of newly } \\
\text { attracted customers }\end{array}$ & 0.08 & 0.20 & 0.10 & 0.10 & 0.20 & 0.10 & 0.30 & 0.15 & 0.154 \\
\hline 2 & $\begin{array}{l}\text { The number of } \\
\text { customers lost }\end{array}$ & 0.08 & 0.30 & 0.10 & 0.05 & 0.15 & 0.08 & 0.01 & 0.20 & 0.121 \\
\hline 3 & $\begin{array}{l}\text { Intensity of } \\
\text { consumption }\end{array}$ & 0.14 & 0.20 & 0.15 & 0.20 & 0.15 & 0.25 & 0.20 & 0.05 & 0.168 \\
\hline 4 & $\begin{array}{l}\text { Material value of } \\
\text { goods or services }\end{array}$ & 0.09 & 0.02 & 0.02 & 0.10 & 0.09 & 0.06 & 0.10 & 0.10 & 0.073 \\
\hline 5 & $\begin{array}{l}\text { Consumer-realised } \\
\text { non-material value of } \\
\text { goods or services }\end{array}$ & 0.24 & 0.02 & 0.25 & 0.10 & 0.11 & 0.13 & 0.10 & 0.15 & 0.138 \\
\hline 6 & $\begin{array}{l}\text { Flexible pricing and } \\
\text { price discrimination }\end{array}$ & 0.09 & 0.02 & 0.15 & 0.05 & 0.07 & 0.15 & 0.03 & 0.10 & 0.083 \\
\hline 7 & $\begin{array}{l}\text { Costs of sales to one } \\
\text { litas of sales }\end{array}$ & 0.18 & 0.14 & 0.12 & 0.20 & 0.09 & 0.05 & 0.20 & 0.10 & 0.135 \\
\hline 8 & $\begin{array}{l}\text { Distribution costs to } \\
\text { one litas of sales }\end{array}$ & 0.06 & 0.05 & 0.08 & 0.10 & 0.08 & 0.08 & 0.02 & 0.10 & 0.071 \\
\hline 9 & $\begin{array}{l}\text { General and } \\
\text { administration costs to } \\
\text { one litas of sales }\end{array}$ & 0.04 & 0.05 & 0.03 & 0.10 & 0.06 & 0.10 & 0.04 & 0.05 & 0.059 \\
\hline & & 1.00 & 1.00 & 1.00 & 1.00 & 1.00 & 1.00 & 1.00 & 1.00 & 1.000 \\
\hline
\end{tabular}


To test the degree of agreement of expert estimates, the ranks of the evaluation criteria are determined: the most important indicator (having the highest relative weight) in case of each $k$-th expert $(k=1, \ldots, r)$ is granted with rank 1 , the second best criterion - with rank 2, etc; while the least important indicator has the rank of $m$ (Table 3). Equivalent indicators have equal ranking - the mean of their consequent rank values (Podvezko 2005).

Table 3. Ranks of expert estimates of evaluation criteria weights

\begin{tabular}{c|c|c|c|c|c|c|c|c|r}
\hline \multirow{2}{*}{ Criteria } & \multicolumn{7}{|c|}{ Ranks of expert estimates } & \multirow{2}{*}{ Sum of ranks } \\
\cline { 2 - 10 } & 1 & 2 & 3 & 4 & 5 & 6 & 7 & 8 & 28.5 \\
\hline 1 & 6.5 & 2.5 & 5.5 & 5 & 1 & 4.5 & 1 & 2.5 & 40.5 \\
\hline 2 & 6.5 & 1 & 5.5 & 8.5 & 2.5 & 6.5 & 9 & 1 & 24 \\
\hline 3 & 3 & 2.5 & 2.5 & 1.5 & 2.5 & 1 & 2.5 & 8.5 & 50 \\
\hline 4 & 4.5 & 8 & 9 & 5 & 5.5 & 8 & 4.5 & 5.5 & 29 \\
\hline 5 & 1 & 8 & 1 & 5 & 4 & 3 & 4.5 & 2.5 & 46 \\
\hline 6 & 4.5 & 8 & 2.5 & 8.5 & 8 & 2 & 7 & 5.5 & 34 \\
\hline 7 & 2 & 4 & 4 & 1.5 & 5.5 & 9 & 2.5 & 5.5 & 52.5 \\
\hline 8 & 8 & 5.5 & 7 & 5 & 7 & 6.5 & 8 & 5.5 & 55.5 \\
\hline 9 & 9 & 5.5 & 8 & 5 & 9 & 4.5 & 6 & 8.5 & 360 \\
\hline Totals & 45 & 45 & 45 & 45 & 45 & 45 & 45 & 45 & \\
\hline
\end{tabular}

The coefficient of concordance is applied for testing, calculated by the formula (Podvezko 2005; Ginevičius et al. 2008a, 2008b):

$$
W=\frac{12 S}{r^{2} m\left(m^{2}-1\right)} .
$$

The value $S$ is calculated by summing squared deviations between the sum $c_{i}$ of all $r$ experts' ranks for each $i$-th criterion $(i=1, \ldots, m)$ and the average $\bar{c}$ of sums of ranks, by applying the formula:

$$
S=\sum_{i=1}^{m}\left(c_{i}-\bar{c}\right)^{2}
$$

while:

$$
c_{i}=\sum_{k=1}^{r} c_{i k},(i=1, \ldots, m),
$$




$$
\bar{c}=\frac{\sum_{i=1}^{m} c_{i}}{m} .
$$

The consistency of estimates is tested by $\chi^{2}$ distribution with $v=m-1$ degrees of freedom:

$$
\chi^{2}=W r(m-1)=\frac{12 S}{r m(m+1)}
$$

In our case $\bar{C}=40, S=1078$ and $W=0.281$. Whereas the calculated value of $\chi^{2}=17.97$ is larger than the critical value of $\chi_{c r}^{2}=15.51$ (with the significance level of $\alpha=0.05$ ), expert estimates are considered to be in agreement, while the average weight estimates are employed for multicriteria evaluation of partial competitive strategies.

\subsection{Forming the integrated competitive strategy of enterprise $A$}

Enterprise A indicated 10 partial competitive strategies in the questionnaire as intended to be implemented (see Appendix 1) - those are compared (ranked) according to their expected impact on the detailed performance indicators (Table 4). Strong correlation between the results obtained by SAW and other multicriteria methods applied (Table 5) confirms their compatibility, while the ranking of strategic alternatives is derived from the average ranks.

\begin{tabular}{|c|c|c|c|c|c|c|c|c|c|}
\hline \multirow{3}{*}{ No } & \multirow{3}{*}{$\begin{array}{l}\text { Partial competitive } \\
\text { strategies }\end{array}$} & \multicolumn{8}{|c|}{ The results of evaluation (method, estimate values, ranks) } \\
\hline & & \multicolumn{2}{|c|}{ SAW } & \multicolumn{2}{|c|}{ TOPSIS } & \multicolumn{2}{|c|}{ VIKOR } & \multicolumn{2}{|c|}{ Averages } \\
\hline & & $S_{j}$ & $\mathrm{R}$ & $C_{j}$ & $\mathrm{R}$ & $Q_{j}$ & $\mathrm{R}$ & $\begin{array}{l}\text { Sum of } \\
\text { ranks }\end{array}$ & $\begin{array}{l}\text { Ultimate } \\
\text { ranks }\end{array}$ \\
\hline 1 & $\begin{array}{l}\text { Strategies targeting market } \\
\text { segments }\end{array}$ & 0.130 & 3 & 0.437 & 3 & 0.542 & 3 & 9 & 3 \\
\hline 2 & $\begin{array}{l}\text { Marketing and promotion } \\
\text { strategies }\end{array}$ & 0.258 & 1 & 0.802 & 1 & 0.000 & 1 & 3 & 1 \\
\hline 3 & Product development strategies & 0.070 & 6 & 0.260 & 6 & 0.785 & 6 & 18 & 6 \\
\hline 4 & $\begin{array}{l}\text { Strategies aimed at creating } \\
\text { the contingent of permanent } \\
\text { customers }\end{array}$ & 0.113 & 4 & 0.395 & 4 & 0.734 & 5 & 13 & 4 \\
\hline 5 & $\begin{array}{l}\text { Strategies targeting distribution } \\
\text { channels }\end{array}$ & 0.183 & 2 & 0.577 & 2 & 0.244 & 2 & 6 & 2 \\
\hline 6 & $\begin{array}{l}\text { Strategies of developing } \\
\text { and maintaining human and } \\
\text { managerial resources }\end{array}$ & 0.107 & 5 & 0.359 & 5 & 0.593 & 4 & 14 & 5 \\
\hline 7 & $\begin{array}{l}\text { Strategies of developing and } \\
\text { maintaining technological } \\
\text { resources }\end{array}$ & 0.033 & 8 & 0.165 & 8 & 0.989 & 9 & 25 & 8 \\
\hline
\end{tabular}

Table 4. The results of multicriteria evaluation of „Partial competitive strategies“, enterprise A 
Continued Table 4

\begin{tabular}{|c|c|c|c|c|c|c|c|c|c|}
\hline \multirow{3}{*}{ No } & \multirow{3}{*}{$\begin{array}{l}\text { Partial competitive } \\
\text { strategies }\end{array}$} & \multicolumn{8}{|c|}{ The results of evaluation (method, estimate values, ranks) } \\
\hline & & \multicolumn{2}{|c|}{ SAW } & \multicolumn{2}{|c|}{ TOPSIS } & \multicolumn{2}{|c|}{ VIKOR } & \multicolumn{2}{|c|}{ Averages } \\
\hline & & $S_{j}$ & $\mathrm{R}$ & $C_{j}$ & $\mathrm{R}$ & $Q_{j}$ & $\mathrm{R}$ & $\begin{array}{c}\text { Sum of } \\
\text { ranks }\end{array}$ & $\begin{array}{l}\text { Ultimate } \\
\text { ranks }\end{array}$ \\
\hline 8 & $\begin{array}{l}\text { Strategies of developing } \\
\text { and maintaining information } \\
\text { systems }\end{array}$ & 0.048 & 7 & 0.187 & 7 & 0.845 & 7 & 21 & 7 \\
\hline 9 & $\begin{array}{l}\text { Strategies aimed at gaining and } \\
\text { maintaining a good name and } \\
\text { reputation of the enterprise }\end{array}$ & 0.032 & 9 & 0.153 & 9 & 0.986 & 8 & 26 & 9 \\
\hline 10 & Response strategies & 0.026 & 10 & 0.116 & 10 & 1.000 & 10 & 30 & 10 \\
\hline
\end{tabular}

Table 5. Correlation of the results of multicriteria evaluation, enterprise A

\begin{tabular}{c|c|c}
\cline { 2 - 3 } \multicolumn{1}{c}{} & TOPSIS & VIKOR \\
\hline SAW & 0.999 & -0.987 \\
\hline
\end{tabular}

It has to be stressed though, that application of the model is not to provide an unambiguous answer or the only right recipe on the composition of the integrated strategy, for the results of multicriteria assessment require additional analysis and interpretation.

The final decision on business strategy is always the prerogative of the office and chief executive of the enterprise, while application of the model allows providing scientifically grounded, based on calculations proposal on the composition of the integrated competitive strategy, according to:

1) the ranking of partial competitive strategies (ratings of strategic alternatives with regard to their expected impact on performance);

2) the values of SAW criterion $S_{j}$ (quantitative and comparable estimates of strategic alternatives' expected impact on performance).

The integrated competitive strategy of enterprise A is proposed to be composed of six groups of partial competitive strategies (indicated with italic font in Table 4): marketing and promotion strategies (rank $1, S_{j}=0.258$ ), strategies targeting distribution channels (rank $2, S_{j}=0.183$ ), strategies targeting market segments (rank $\left.3, S_{j}=0.130\right)$, strategies aimed at creating the contingent of permanent customers (rank $4, S_{j}=0.113$ ), strategies of developing and maintaining human and managerial resources (rank $5, S_{j}=0.107$ ), and product development strategies (rank $6, S_{j}=0.070$ ). The remaining four strategic alternatives, with regard to their ratings (7-10) and the values of criterion $S_{j}$ (between 0.026 and 0.048), are suggested not to be included in the integrated competitive strategy.

SAW method estimates are considered to be the basis for calculating the scales of partial competitive strategies (relative weights in the integrated strategy): with the integrated competitive strategy of enterprise A being composed of six groups of partial strategies, 
having the most significant impact on performance, the normalised values of criterion $S_{j}\left(\sum_{j=1}^{6} \tilde{S}_{j}=1\right)$ enable to quantitatively evaluate the scales of partial strategies and form the structure of enterprise A integrated competitive strategy (Fig. 1).

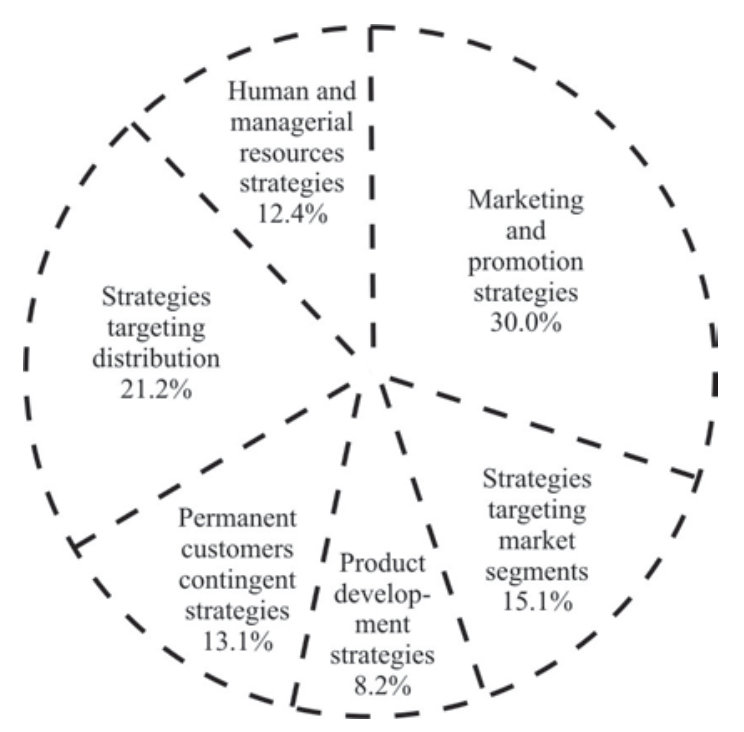

Fig. 1. The structure of the integrated competitive strategy of enterprise A

The structure of the integrated competitive strategy, on one hand, reflects the expected contribution of every detailed strategy to enterprise performance; on the other hand, the shares of partial competitive strategies are considered to be the quantitative indicators for the purpose of setting up long-term goals and choosing the main directions of business strategy of an enterprise, distributing financial, human and other resources for strategic actions to be designed and implemented.

\subsection{Forming the integrated competitive strategy of enterprise $B$}

Enterprise B indicated 13 partial competitive strategies in the questionnaire as intended to be implemented (see Appendix 2). The strategies chosen are ranked according to their expected impact on the detailed performance indicators (Table 6), checking the compatibility of the results obtained by the multicriteria methods applied (Table 7).

Correlation analysis discloses the diverging results of VIKOR, with the correlation coefficient (modulus value) with SAW being less than 0.8 . Thus, only SAW and TOPSIS methods are considered for ranking the strategic alternatives in case of enterprise B.

With regard to the ranking of partial strategies and the values of SAW method criterion $S_{j}$, the integrated competitive strategy of enterprise B is proposed to be composed of 
Table 6. The results of multicriteria evaluation of partial competitive strategies, enterprise B

\begin{tabular}{|c|c|c|c|c|c|c|c|c|c|}
\hline \multirow{3}{*}{ No } & \multirow{3}{*}{ Partial competitive strategies } & \multicolumn{8}{|c|}{ The results of evaluation (method, estimate values, ranks) } \\
\hline & & \multicolumn{2}{|c|}{ SAW } & \multicolumn{2}{|c|}{ TOPSIS } & \multicolumn{2}{|c|}{ VIKOR } & \multicolumn{2}{|c|}{$\begin{array}{l}\text { Averages (SAW } \\
\text { and TOPSIS) }\end{array}$} \\
\hline & & $S_{j}$ & $\mathrm{R}$ & $C_{j}$ & $\mathrm{R}$ & $Q_{j}$ & $\mathrm{R}$ & $\begin{array}{l}\text { Sum } \\
\text { of } \\
\text { ranks }\end{array}$ & $\begin{array}{l}\text { Ultimate } \\
\text { ranks }\end{array}$ \\
\hline 1 & Market expansion strategies & 0.063 & 8 & 0.279 & 6 & 0.341 & 5 & 14 & 7 \\
\hline 2 & $\begin{array}{l}\text { Strategies targeting market } \\
\text { segments }\end{array}$ & 0.156 & 1 & 0.516 & 1 & 0.000 & 1 & 2 & 1 \\
\hline 3 & $\begin{array}{l}\text { Marketing and promotion } \\
\text { strategies }\end{array}$ & 0.093 & 5 & 0.362 & 4 & 0.231 & 3 & 9 & 4 \\
\hline 4 & $\begin{array}{l}\text { Product development } \\
\text { strategies }\end{array}$ & 0.045 & 10 & 0.179 & 10 & 0.611 & 7 & 20 & 10 \\
\hline 5 & $\begin{array}{l}\text { Strategies aimed at creating } \\
\text { the contingent of permanent } \\
\text { customers }\end{array}$ & 0.041 & 11 & 0.138 & 11 & 0.821 & 8 & 22 & 11 \\
\hline 6 & Strategies targeting suppliers & 0.071 & 6 & 0.344 & 5 & 0.840 & 9 & 11 & 5 \\
\hline 7 & $\begin{array}{l}\text { Strategies targeting } \\
\text { distribution channels }\end{array}$ & 0.067 & 7 & 0.239 & 9 & 0.392 & 6 & 16 & $8-9$ \\
\hline 8 & $\begin{array}{l}\text { Strategies of developing } \\
\text { and maintaining human and } \\
\text { managerial resources }\end{array}$ & 0.095 & 4 & 0.244 & 8 & 0.900 & 12 & 12 & 6 \\
\hline 9 & $\begin{array}{l}\text { Strategies of developing and } \\
\text { maintaining technological } \\
\text { resources }\end{array}$ & 0.120 & 3 & 0.440 & 2 & 0.135 & 2 & 5 & $2-3$ \\
\hline 10 & $\begin{array}{l}\text { Strategies of developing and } \\
\text { maintaining information } \\
\text { systems }\end{array}$ & 0.062 & 9 & 0.266 & 7 & 0.872 & 11 & 16 & $8-9$ \\
\hline 11 & $\begin{array}{l}\text { Strategies aimed at gaining } \\
\text { and maintaining a good } \\
\text { name and reputation of the } \\
\text { enterprise }\end{array}$ & 0.023 & 13 & 0.093 & 13 & 0.984 & 13 & 26 & 13 \\
\hline 12 & Defensive strategies & 0.033 & 12 & 0.126 & 12 & 0.851 & 10 & 24 & 12 \\
\hline 13 & Response strategies & 0.131 & 2 & 0.439 & 3 & 0.285 & 4 & 5 & $2-3$ \\
\hline
\end{tabular}

Table 7. Correlation of the results of multicriteria evaluation, enterprise B

\begin{tabular}{c|c|c}
\cline { 2 - 3 } & TOPSIS & VIKOR \\
\hline SAW & 0.946 & -0.763 \\
\hline
\end{tabular}


nine groups of partial competitive strategies (indicated with italic font in Table 6): strategies targeting market segments (rank $1, S_{j}=0.156$ ), response strategies (rank 2-3, $S_{j}=0.131$ ), strategies of developing and maintaining technological resources (rank $2-3, S_{j}=0.120$ ), marketing and promotion strategies (rank $4, S_{j}=0.093$ ), strategies targeting suppliers (rank $5, S_{j}=0.071$ ), strategies of developing and maintaining human and managerial resources (rank $6, S_{j}=0.095$ ), market expansion strategies (rank 7, $S_{j}=0.063$ ), strategies targeting distribution channels ( $\operatorname{rank} 8-9, S_{j}=0.067$ ), and strategies of developing and maintaining information systems ( $\operatorname{rank} 8-9, S_{j}=0.062$ ). The remaining four strategic alternatives, with regard to their ratings $(10-13)$ and the values of criterion $S_{j}$ (between 0.023 and 0.045 ), are suggested not to be included in the integrated strategy. The structure of the integrated competitive strategy of enterprise B is designed by normalising the values of SAW criterion $S_{j}\left(\sum_{j=1}^{9} \tilde{S}_{j}=1\right)$ for nine par-
tial strategies chosen (Fig. 2).

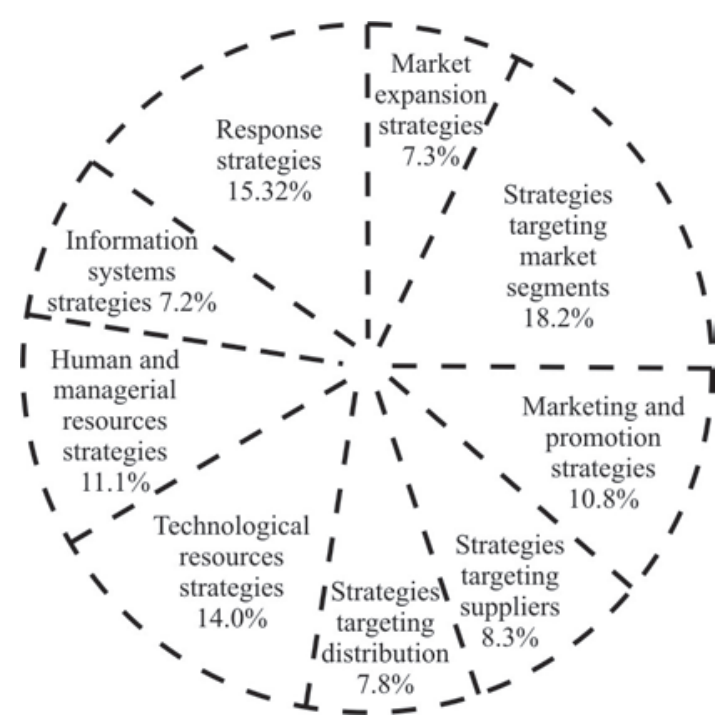

Fig. 2. The structure of the integrated competitive strategy of enterprise B

\subsection{Forming the integrated competitive strategy of enterprise $C$}

Enterprise $\mathrm{C}$ indicated 13 partial competitive strategies in the questionnaire as intended to be implemented (see Appendix 3).

The strategies chosen are ranked according to their expected impact on the detailed performance indicators (Table 8), while the strong correlation between the results obtained (modulus of correlation coefficients exceed 0.8 ) confirms the compatibility of the multicriteria methods applied (Table 9). 
Table 8. The results of multicriteria evaluation of partial competitive strategies, enterprise $\mathrm{C}$

\begin{tabular}{|c|c|c|c|c|c|c|c|c|c|}
\hline \multirow{3}{*}{ No } & \multirow{3}{*}{$\begin{array}{l}\text { Partial competitive } \\
\text { strategies }\end{array}$} & \multicolumn{8}{|c|}{ The results of evaluation (method, estimate values, ranks) } \\
\hline & & \multicolumn{2}{|c|}{ SAW } & \multicolumn{2}{|c|}{ TOPSIS } & \multicolumn{2}{|c|}{ VIKOR } & \multicolumn{2}{|c|}{ Averages } \\
\hline & & $S_{j}$ & $\mathrm{R}$ & $C_{j}$ & $\mathrm{R}$ & $Q_{j}$ & $\mathrm{R}$ & $\begin{array}{l}\text { Sum of } \\
\text { ranks }\end{array}$ & $\begin{array}{l}\text { Ultimate } \\
\text { ranks }\end{array}$ \\
\hline 1 & $\begin{array}{l}\text { Market expansion } \\
\text { strategies }\end{array}$ & 0.018 & 13 & 0.051 & 13 & 1.000 & 13 & 39 & 13 \\
\hline 2 & $\begin{array}{l}\text { Marketing and promotion } \\
\text { strategies }\end{array}$ & 0.073 & 8 & 0.372 & 8 & 0.540 & 7 & 23 & 8 \\
\hline 3 & $\begin{array}{l}\text { Product development } \\
\text { strategies }\end{array}$ & 0.115 & 2 & 0.593 & 2 & 0.047 & 1 & 5 & 1 \\
\hline 4 & $\begin{array}{l}\text { Strategies aimed at } \\
\text { creating the contingent of } \\
\text { permanent customers }\end{array}$ & 0.038 & 12 & 0.184 & 12 & 0.847 & 12 & 36 & 12 \\
\hline 5 & $\begin{array}{l}\text { Strategies targeting } \\
\text { suppliers }\end{array}$ & 0.074 & 7 & 0.396 & 7 & 0.596 & 8 & 22 & 7 \\
\hline 6 & $\begin{array}{l}\text { Strategies targeting } \\
\text { distribution channels }\end{array}$ & 0.146 & 1 & 0.637 & 1 & 0.375 & 4 & 6 & 2 \\
\hline 7 & $\begin{array}{l}\text { Strategies of developing } \\
\text { and maintaining human } \\
\text { and managerial resources }\end{array}$ & 0.075 & 6 & 0.410 & 6 & 0.446 & 6 & 18 & 6 \\
\hline 8 & $\begin{array}{l}\text { Strategies of developing } \\
\text { and maintaining } \\
\text { technological resources }\end{array}$ & 0.112 & 3 & 0.567 & 4 & 0.266 & 3 & 10 & 4 \\
\hline 9 & $\begin{array}{l}\text { Strategies of developing } \\
\text { and maintaining } \\
\text { information systems }\end{array}$ & 0.048 & 11 & 0.236 & 11 & 0.680 & 11 & 33 & 11 \\
\hline 10 & $\begin{array}{l}\text { Strategies aimed at } \\
\text { gaining and maintaining } \\
\text { a good name and } \\
\text { reputation of the } \\
\text { enterprise }\end{array}$ & 0.086 & 5 & 0.459 & 5 & 0.392 & 5 & 15 & 5 \\
\hline 11 & Defensive strategies & 0.057 & 9 & 0.291 & 9 & 0.625 & 9 & 27 & 9 \\
\hline 12 & Response strategies & 0.052 & 10 & 0.241 & 10 & 0.659 & 10 & 30 & 10 \\
\hline 13 & $\begin{array}{l}\text { Collaboration and } \\
\text { cooperation strategies }\end{array}$ & 0.106 & 4 & 0.567 & 3 & 0.083 & 2 & 9 & 3 \\
\hline
\end{tabular}

Table 9. Correlation of the results of multicriteria evaluation, enterprise $\mathrm{C}$

\begin{tabular}{c|c|c}
\cline { 2 - 3 } & \multicolumn{1}{c|}{ TOPSIS } & VIKOR \\
\hline SAW & 0.980 & -0.863 \\
\hline
\end{tabular}


With regard to the ranking of partial strategies and the values of SAW method criterion $S_{j}$, the integrated competitive strategy of enterprise C is proposed to be composed of eight groups of partial competitive strategies (indicated with italic font in Table 8): product development strategies ( $\operatorname{rank} 1, S_{j}=0.115$ ), strategies targeting distribution channels (rank 2, $S_{j}=0.146$ ), collaboration and cooperation strategies (rank 3, $S_{j}=0.106$ ), strategies of developing and maintaining technological resources (rank 4, $S_{j}=0.112$ ), strategies aimed at gaining and maintaining a good name and reputation of the enterprise (rank $5, S_{j}=0.086$ ), strategies of developing and maintaining human and managerial resources (rank $6, S_{j}=0.075$ ), strategies targeting suppliers (rank 7, $S_{j}=0.074$ ), and marketing and promotion strategies (rank $8, S_{j}=0.073$ ). The remaining five strategic alternatives, with regard to their ratings (9-13) and the values of criterion $S_{j}$ (between 0.018 and 0.057), are suggested not to be included in the integrated strategy. The structure of the integrated competitive strategy of enterprise $\mathrm{C}$ is designed by normalising the values of SAW criterion $S_{j}\left(\sum_{j=1}^{8} \tilde{S}_{j}=1\right)$ for eight partial
strategies chosen (Fig. 3).

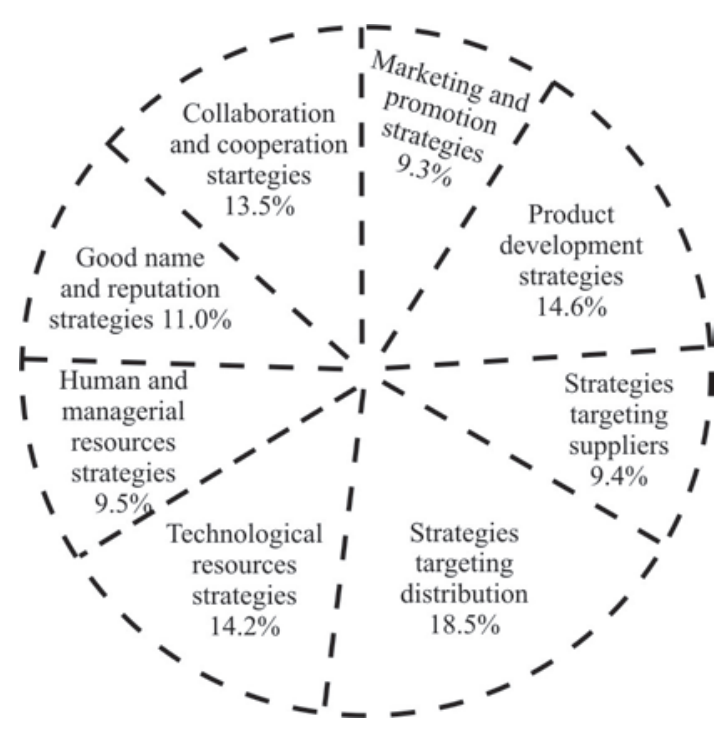

Fig. 3. The structure of the integrated competitive strategy of enterprise C

\section{Conclusions}

The article proposes scientifically brand new, complex approach to forming competitive strategy, based on the assumption that oligopolic enterprise implements strategic actions of various purposes and directions, treated as composite elements of the integrated competitive strategy, i.e. partial competitive strategies. The strategy of oligopolic enterprise is multiple and complex, therefore it should be divided (decomposed) into partial 
competitive strategies in order to estimate the impact of certain strategic activities on performance, to make suggestions for business strategy development and modification. The results of the research, presented in the article, are summarised by the following conclusions:

1. According to the model proposed, forming competitive strategy of oligopolic enterprise involves the selection of the strategic alternatives (partial competitive strategies) intended to be implemented, and the comparative assessment of their expected impact on performance indicators in order to identify the most favourable strategic alternatives to comprise the integrated strategy, and to determine their scales (relative weights in the integrated strategy). Multicriteria methods are applied for quantitative assessment, where the partial competitive strategies are the alternatives under evaluation, while the criteria for evaluation are represented by the system of enterprise performance indicators, aimed at the ultimate financial result - profit or loss.

2. The main results of model application are scientifically grounded proposals on forming the competitive strategies of the enterprises under research. However, it is stressed that the decision on selecting the strategic alternatives is the prerogative of the office and chief executive of an enterprise, while the model is considered to be a tool to perform the necessary calculations and generate a well-founded proposal on forming the integrated strategy.

3. The structures of the integrated competitive strategies, designed by applying the model, enable to quantitatively compare the expected efficiency of various strategic alternatives, to indicate the main priorities of enterprise business strategy, to distribute financial, human and other resources for strategic actions to be designed and implemented.

4. The factors, influencing the results of model application, the possibilities to extend the model or apply it more flexibly, together with the niches for further research, are indicated:

4.1. The list of partial strategies to form the integrated competitive strategy is generally based on a wide scope of scientific sources of strategic management and theoretical oligopoly models. However, the model could be flexibly complimented with the specific strategic alternatives, intended to be implemented by the particular enterprise, on condition that newly included partial strategies influence the detailed performance indicators, and thus, could be assessed with regard to the designed system of evaluation criteria.

4.2. Profit-loss analysis was assumed to generate the system of partial strategies' evaluation criteria, where the detailed performance indicators reflect enterprise's residual demand, its revenues from one unit of sales and costs to one litas of sales; moreover, the number of indicators was limited due to practical considerations (for the research questionnaire to be of adequate size). Practical application of the model could involve additional performance indicators, necessary for the assessment of strategic alternatives in case of the particular enterprise, although, it is recommended to keep the whole set of detailed indicators aimed at the ultimate financial result, as the main goal of business owners. 
4.3. The scale for assessing the impact of enterprise's environment on application of partial competitive strategies (favourable, unfavourable, neutral) and the impact of partial strategies on performance indicators (measured by points from -3 to 3 ) could be supplemented with the methodology of applying the scales (e.g. numeric values of the indicators, corresponding to the particular point-values of strategies' impact; the questionnaires for enterprise environment-conduct analysis, enabling to estimate the impact of environment on the certain partial strategy, etc) - this possibility to extend the model is proposed as a niche for further research.

\section{References}

Ansoff, I. H. 1984. Implanting Strategic Management. New Jersey: Prentice Hall International.

Barney, J. B. 1991. Firm Resources and Sustained Competitive Advantage, Journal of Management 17(1): 99-120. doi:10.1177/014920639101700108

Bivainis, J.; Staškevičius, A. T. 2004. Imonès daugiakomponentės strategijos modeliavimas [Modelling of enterprise multicomponent strategy], Verslas: teorija ir praktika [Business: Theory and Practice] 5(4): 152-156 (in Lithuanian).

Bivainis, J.; Zinkevičiūtè, V. 2006. Verslo strateginių sprendimų pasirinkimo pagrindimas [Reasoning of business strategic decisions selection], Technological and Economic Development of Economy 12(2): 99-107 (in Lithuanian).

Časas, R. 2000. Imoniu konkuravimo strategiju šaltiniu atpažinimas ir ìvertinimas Lietuvos rinkoje [Indication and evaluation of the sources of enterprise competitive strategies in Lithuanian market]. Doctoral Dissertation. Vilnius: VU. 196 p. (in Lithuanian).

David, F. F. 2007. Strategic Management: Concepts and Cases. 11th Ed. New Jersey: Prentice Hall. Friedman, J. W. 1969. Symposium on experimental economics: on experimental research in oligopoly, Review of Economic Studies 36(108): 399-415. doi:10.2307/2296467

Friedman, J. W. 1971. A noncooperative view of oligopoly, International Economic Review 12(1): 106-122. doi:10.2307/2525500

Friedman, J. W. 1988. On the strategic importance of prices versus quantities, RAND Journal of Economics 19(4): 607-622. doi:10.2307/2555460

Ginevičius, R. 1998. Imoniu veiklos diversifikacija [Diversification of Enterprise Activities]. Vilnius: Technika. 152 p. (in Lithuanian).

Ginevičius, R. 2000. Imoniu prisitaikymo prie išorès aplinkos strategijos [Strategies of adaptation of enterprises to the environment], Verslas: teorija ir praktika [Business: Theory and Practice] 1(1): 10-17 (in Lithuanian).

Ginevičius, R. 2008. Normalization of quantities of various dimensions, Journal of Business Economics and Management 9(1): 79-86. doi:10.3846/1611-1699.2008.9.79-86

Ginevičius, R. 2009. Quantitative evaluation of unrelated diversification of enterprise activities, Journal of Civil Engineering and Management 15(1): 105-111. doi:10.3846/1392-3730.2009.15.105-111

Ginevičius, R.; Čirba, S. 2005. Rodikliu reikšmių transformavimas atliekant daugiakriterinius vertinimus [Normalization of the Criteria Values in Multicriteria Evaluation], Verslas: teorija ir praktika [Business: Theory and Practice] 6(3): 125-130 (in Lithuanian).

Ginevičius, R.; Krivka, A. 2008a. Application of game theory for doupoly market analysis, Journal of Business Economics and Management 9(3): 207-217. doi:10.3846/1611-1699.2008.9.207-217

Ginevičius, R.; Krivka, A. 2008b. Optimali rinkos struktūra: laisva konkurencija ir vartotojų suverenumas [Optimal market structure: free competition and consumer sovereignty], Verslas: teorija ir 
praktika [Business: Theory and Practice] 9(4): 306-312 (in Lithuanian). doi:10.3846/1648-0627.2008.9.306-312

Ginevičius, R.; Krivka, A. 2009a. Konkurencinès aplinkos oligopolinėje rinkoje daugiakriterinis vertinimas [Multicriteria evaluation of the competitive environment in the oligopolic market], Verslas: teorija ir praktika [Business: Theory and Practice] 10(4): 247-258 (in Lithuanian).

doi:10.3846/1648-0627.2009.10.247-258

Ginevičius, R.; Krivka, A. 2009b. Verslo koncentracijos Lietuvos ekonomikoje tyrimas [The research on business concentration in Lithuanian economy], Verslas: teorija ir praktika [Business: Theory and Practice] 10(3): 191-203 (in Lithuanian). doi:0.3846/1648-0627.2009.10.191-203

Ginevičius, R.; Podvezko, V. 2004. Imonių strateginio potencialo kiekybinis ivvertinimas [Quantitative evaluation of the strategic potential of enterprises], Verslas: teorija ir praktika [Business: Theory and Practice] 5(1): 3-9 (in Lithuanian).

Ginevičius, R.; Podvezko, V. 2006. Assessing the financial state of construction enterprises, Technological and Economic Development of Economy 12(3): 188-194.

Ginevičius, R.; Podvezko, V. 2008a. Daugiakriterinio vertinimo būdų suderinamumas [The problem of compatibility of various multiple criteria evaluation methods], Verslas: teorija ir praktika [Business: Theory and Practice] 9(1): 73-80 (in Lithuanian). doi:10.3846/1648-0627.2008.9.73-80

Ginevičius, R.; Podvezko, V. 2008b. Multicriteria evaluation of Lithuanian banks from the perspective of their reliability for clients, Journal of Business Economics and Management 9(4): 257-267. doi:10.3846/1611-1699.2008.9.257-267

Ginevičius, R.; Podvezko, V. 2008c. Multicriteria graphical-analytical evaluation of the financial state of construction enterprises, Technological and Economic Development of Economy 14(4): 452-461. doi:10.3846/1392-8619.2008.14.452-461

Ginevičius, R.; Podvezko, V. 2009. Evaluating the changes in economic and social development of Lithuanian counties by multiple criteria methods, Technological and Economic Development of Economy 15(3): 418-436. doi:10.3846/1392-8619.2009.15.418-436

Ginevičius, R.; Zubrecovas, V. 2009. Selection of the optimal real estate investment project basing on multiple criteria evaluation using stochastic dimensions, Journal of Business Economics and Management 10(3): 261-270. doi:10.3846/1611-1699.2009.10.261-270

Ginevičius, R.; Butkevičius, A.; Podvezko, V. 2005. Naujų Europos Sajungos šalių ekonominès plètros daugiakriterinis ivertinimas [Multicriteria evaluation of economic development of new EU memberstates], Verslas: teorija ir praktika [Business: Theory and Practice] 6(2): 85-93 (in Lithuanian).

Ginevičius, R.; Podvezko, V.; Bruzgè, Š. 2008a. Evaluating the effect of state aid to business by multicriteria methods, Journal of Business Economics and Management 9(3): 167-180.

doi:10.3846/1611-1699.2008.9.167-180

Ginevičius, R.; Podvezko, V.; Raslanas, S. 2008b. Evaluating the alternative solutions of wall insulation by multicriteria methods, Journal of Civil Engineering and Management 14(4): 217-226. doi:10.3846/1392-3730.2008.14.20

Grant, R. M. 1991. The resource-based theory of competitive advantage: implications for strategy formulation, California Management Review 33(3): 114-135.

Grant, R. M. 1996. Toward a knowledge-based theory of the firm, Strategic Management Journal 17: 109-122.

Gronskas, V. 2005. Ekonomine analize [Economic analysis]. Kaunas: Technologija (in Lithuanian).

Juozaitienè, L. 2007. Imonés finansai: analize ir valdymas [Enterprise finance: analysis and management]. Šiauliai: Vš̨ Šiaulių universiteto leidykla (in Lithuanian).

Korsakienè, R. 2004. Konkurencinis pranašumas: dviejų požiūrių sintezė [Competitive advantage: the synthesis of two approaches], Verslas: teorija ir praktika [Business: Theory and Practice] 5(2): 52-58 (in Lithuanian). 
Kotler, P.; Keller, K. L. 2006. Marketing Management. 12th Ed. New Jersey: Prentice Hall.

Krivka, A.; Ginevičius, R. 2009. Rinkos struktūra konkurencinès strategijos formavimo kontekste [Market structure in the context of developing competitive strategy], Mokslas - Lietuvos ateitis [Science - Future of Lithuania] 1(3): 34-37 (in Lithuanian).

Opricovic, S.; Tzeng, G. 2004. Compromise solution by MCDM methods: a comparative analysis of VIKOR and TOPSIS, European Journal of Operational Research 156(2): 445-455. doi:10.1016/S0377-2217(03)00020-1

Peteraf, M. A. 1993. The cornerstones of competitive advantage: a resource-based view, Strategic Management Journal 14: 179-191. doi:10.1002/smj.4250140303

Podvezko, V. 2005. Ekspertu ịverčių suderinamumas [Agreement of Expert Estimates], Technological and Economic Development of Economy 11(2): 101-107 (in Lithuanian).

Podvezko, V. 2008. Sudetingų dydžių kompleksinis vertinimas [Comprehensive evaluation of complex quantities], Verslas: teorija ir praktika [Business: Theory and Practice] 9(3): 160-168 (in Lithuanian). doi:10.3846/1648-0627.2008.9.160-168

Porter, M. 1979. How competitive forces shape strategy, Harvard Business Review 57(2): 137-145.

Porter, M. 1998a. Competitive Advantage: Creating and Sustaining Superior Performance. New York: The Free Press.

Porter, M. 1998b. Competitive Strategy: Techniques for Analyzing Industries and Competitors. New York: The Free Press.

Prahalad, C. K.; Hamel, G. 1990. The core competence of the corporation, Harvard Business Review 68(3): 79-91.

Raguseo, D. 2009. Static and dynamic quantity-setting games: an in-class experiment, Verslas: teorija ir praktika [Business: Theory and Practice] 10(4): 308-314.

doi:10.3846/1648-0627.2009.10.308-314

Raudeliūnienè, J. 2007. Imoniu konkuravimo strateginiu sprendimu formavimas [Formation of competitive strategic decisions]. Doctoral Dissertation. Vilnius: VGTU. 150 p. (in Lithuanian).

Sekliuckienè, J. 2006. Organizacijos ištekliu ivveiklinimo siekiant konkurencinio pranašumo modelis [Model of leveraging organizational resources to achieve competitive advantage]. Doctoral Dissertation. Kaunas: KTU. 160 p. (in Lithuanian).

Teece, D. J.; Pisano, G.; Shuen, A. 1997. Dynamic Capabilities and Strategic Management, Strategic Management Journal 18(7): 509-533.

doi:10.1002/(SICI)1097-0266(199708)18:7<509::AID-SMJ882>3.0.CO;2-Z

Thompson, A.; Strickland, A. J.; Gamble, J. E. 2005. Crafting and Executing Strategy: The Quest for Competitive Advantage: Concepts and Cases. Boston: McGraw-Hill.

Von Neumann, J.; Morgenstern, O. 1953. Theory of Games and Economic Behavior. 3rd Ed. London: Oxford University Press.

Zavadskas, E. K.; Kaklauskas, A.; Banaitienè, N. 2001. Pastato gyvavimo proceso daugiakriterine analize [Multicriteria analysis of the state of construction]. Vilnius: Technika (in Lithuanian).

Zavadskas, E. K.; Kaklauskas, A.; Turskis, Z.; Tamošaitienė, J. 2008. Selection of the effective dwelling house walls by applying attributes values determined at intervals, Journal of Civil Engineering and Management 14(2): 85-93. doi:10.3846/1392-3730.2008.14.3

Zavadskas, E. K.; Simanauskas, L.; Kaklauskas, A. 1998. Sprendimu paramos sistemos statyboje [Decision Supporting Systems in Construction]. Vilnius: Technika (in Lithuanian).

Zavadskas, E. K.; Vilutienė, T.; Turskis, Z.; Tamošaitienė, J. 2010. Contractor selection for construction works by applying SAW-G and TOPSIS GREY techniques, Journal of Business Economics and Management 11(1): 34-55. doi:10.3846/jbem.2010.03 


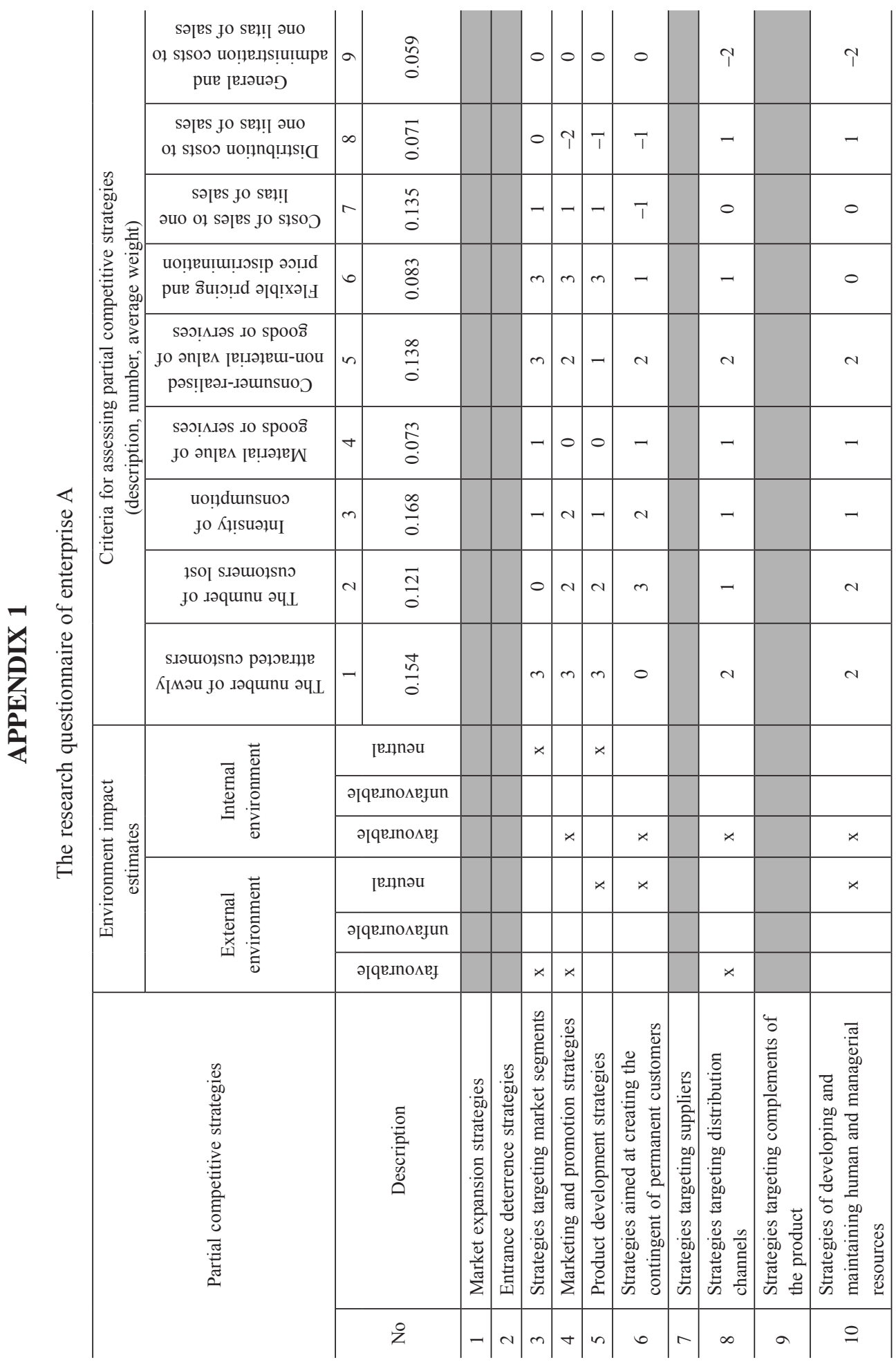


R. Ginevičius, A. Krivka, J. Šimkūnaitè. The model of forming competitive strategy of an enterprise...

\begin{tabular}{|c|c|c|c|c|c|c|c|c|c|c|}
\hline \multirow{9}{*}{ 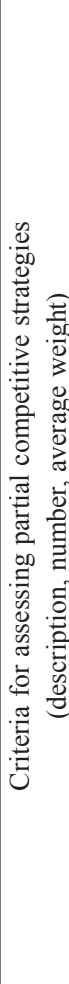 } & 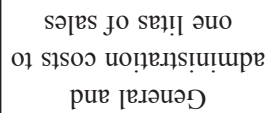 & 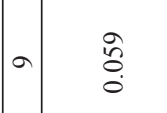 & $p$ & $p$ & $\tau$ & & & 0 & & \\
\hline & 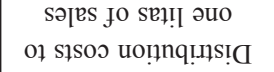 & o. & 0 & -1 & -1 & & & $\uparrow$ & & \\
\hline & 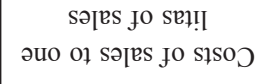 & $\stackrel{n}{m}$ & -1 & 0 & 0 & & & 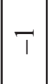 & & \\
\hline & 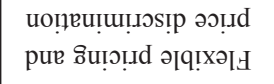 & $\begin{array}{l}\tilde{0} \\
\stackrel{0}{0} \\
0\end{array}$ & - & $m$ & 0 & & & -1 & & \\
\hline & 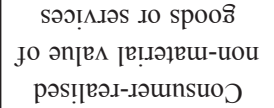 & $\stackrel{\infty}{m}$ & $N$ & 0 & - & & & $v$ & & \\
\hline & 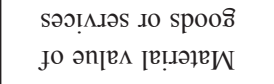 & $\stackrel{m}{0}$ & - & 0 & 0 & & & $N$ & & \\
\hline & 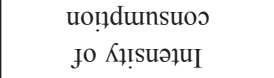 & $\begin{array}{l}\infty \\
\stackrel{\infty}{0} \\
0\end{array}$ & 0 & -1 & 0 & & & 0 & & \\
\hline & 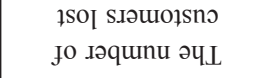 & $\stackrel{\vec{I}}{\overrightarrow{0}}$ & - & -1 & $N$ & & & $N$ & & \\
\hline & 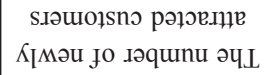 & $\stackrel{\frac{4}{6}}{\stackrel{0}{0}}$ & -1 & -1 & $N$ & & & -1 & & \\
\hline \multirow{6}{*}{ 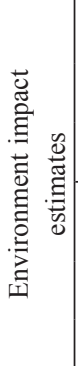 } & \multirow{3}{*}{ 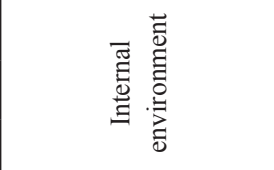 } & 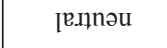 & $x$ & & & & & & & \\
\hline & & әүq..nольвјun & & & $x$ & & & $\star$ & & \\
\hline & & ગqв.nоนеЈ & & $x$ & & & & & & \\
\hline & \multirow{3}{*}{ 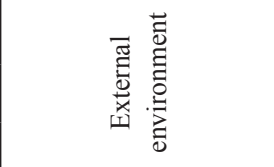 } & [ణ..ฺnəu & & & $x$ & & & $\star$ & & \\
\hline & & әүұв.пnолејип & $x$ & $x$ & & & & & & \\
\hline & & ә૧૯.Inомв] & & & & & & & & \\
\hline & \multirow[t]{2}{*}{ 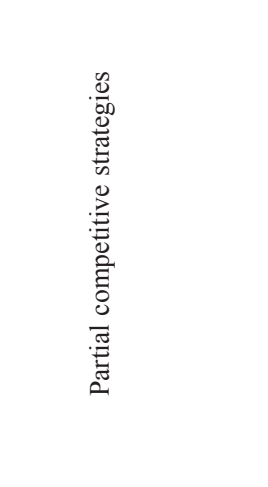 } & 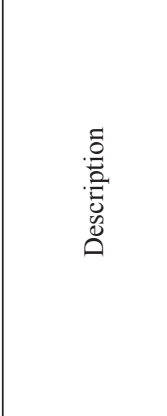 & 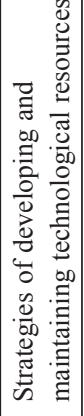 & 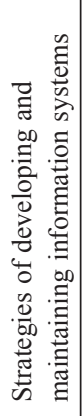 & 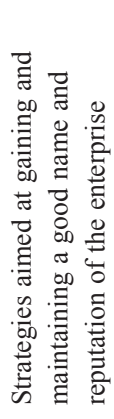 & 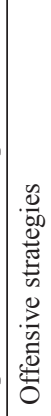 & 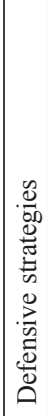 & 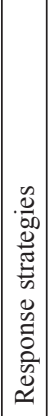 & 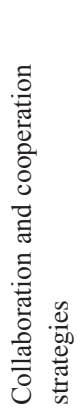 & 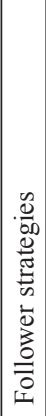 \\
\hline & & ż & $\exists$ & $\approx$ & $\cong$ & \pm & $\because$ & $\mathscr{0}$ & $\beth$ & $\stackrel{\infty}{\sim}$ \\
\hline
\end{tabular}


Journal of Business Economics and Management, 2010, 11(3): 367-395

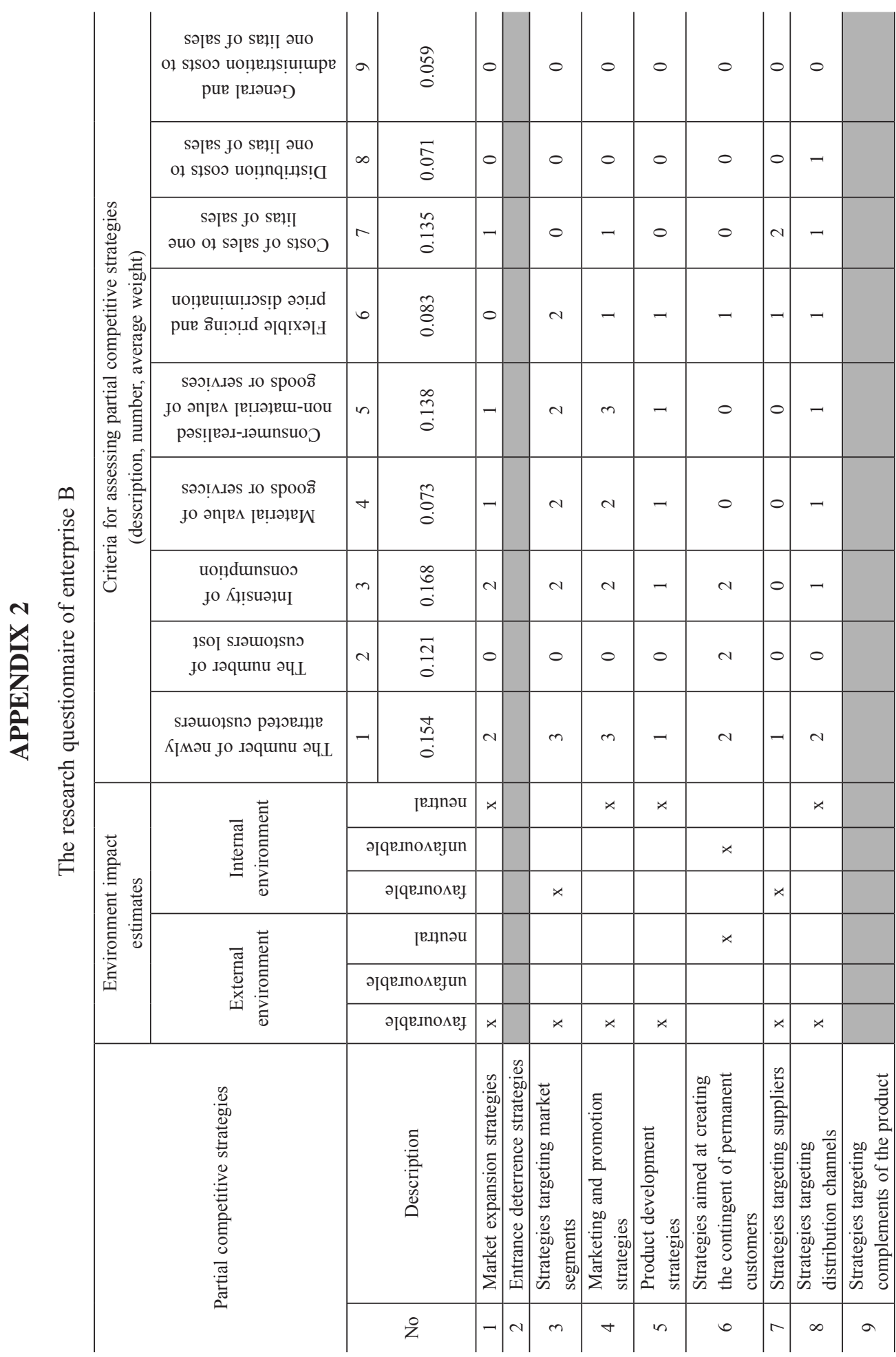


R. Ginevičius, A. Krivka, J. Šimkünaite. The model of forming competitive strategy of an enterprise...

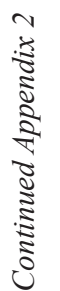

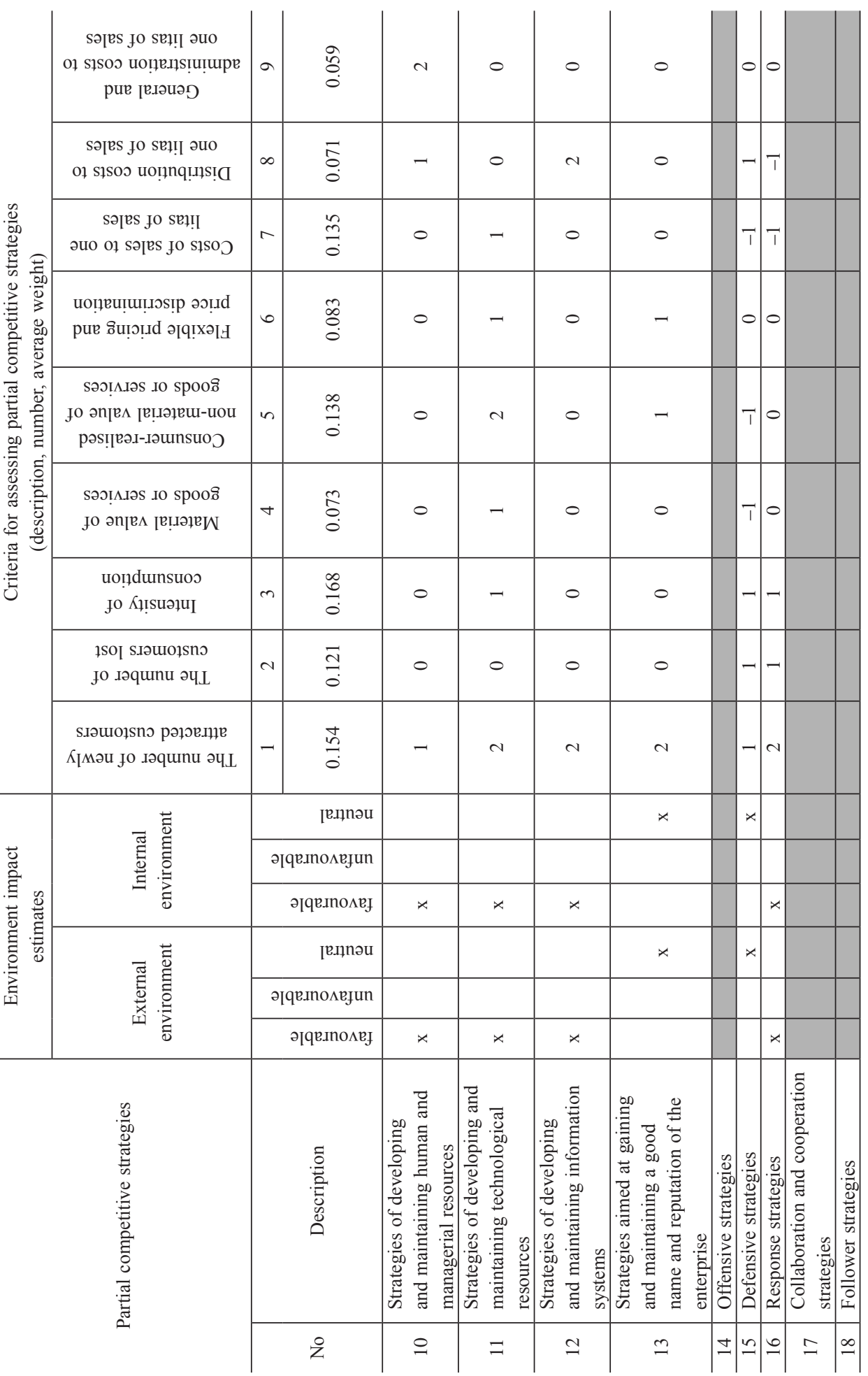


Journal of Business Economics and Management, 2010, 11(3): 367-395

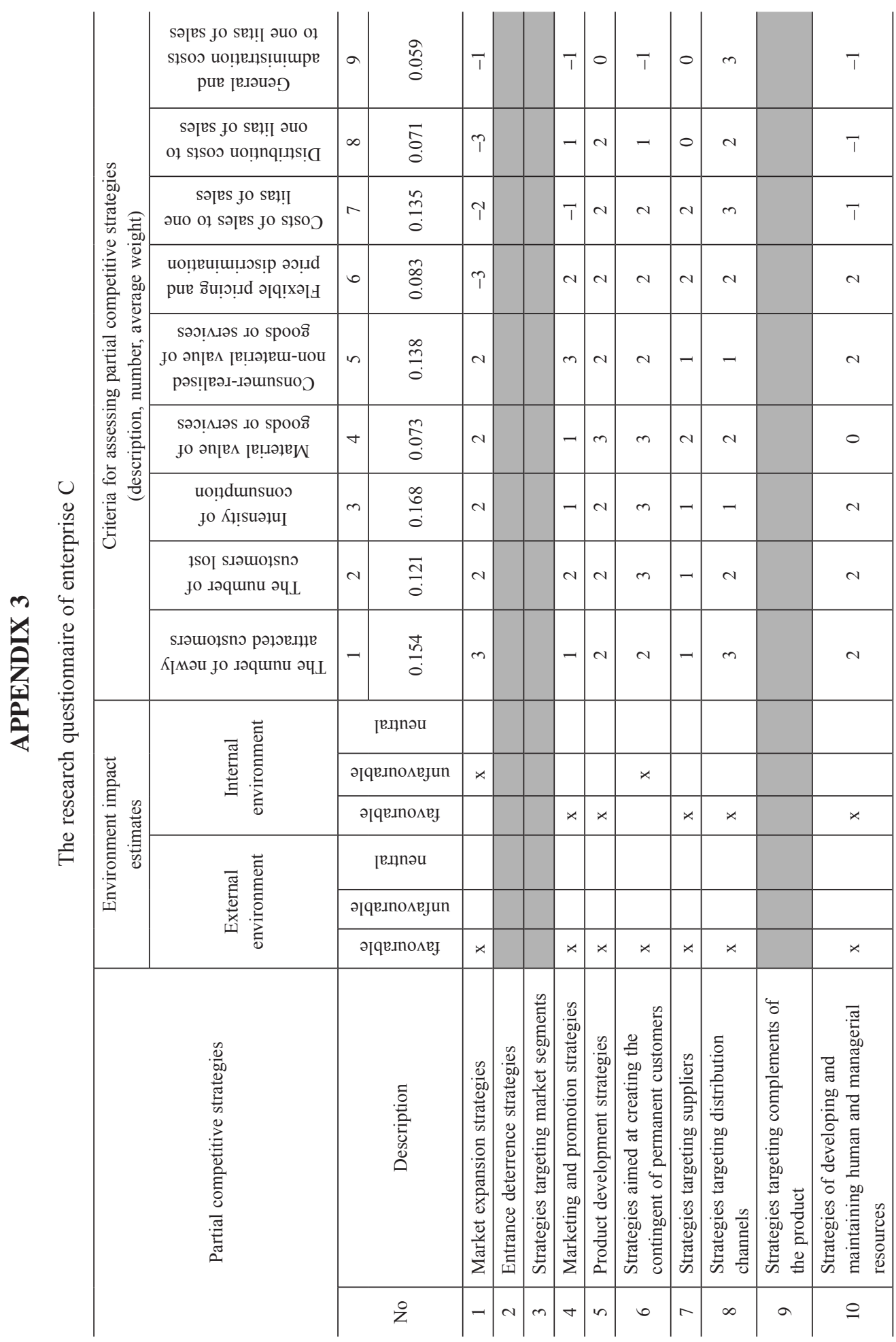


R. Ginevičius, A. Krivka, J. Šimkūnaitè. The model of forming competitive strategy of an enterprise...

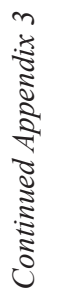

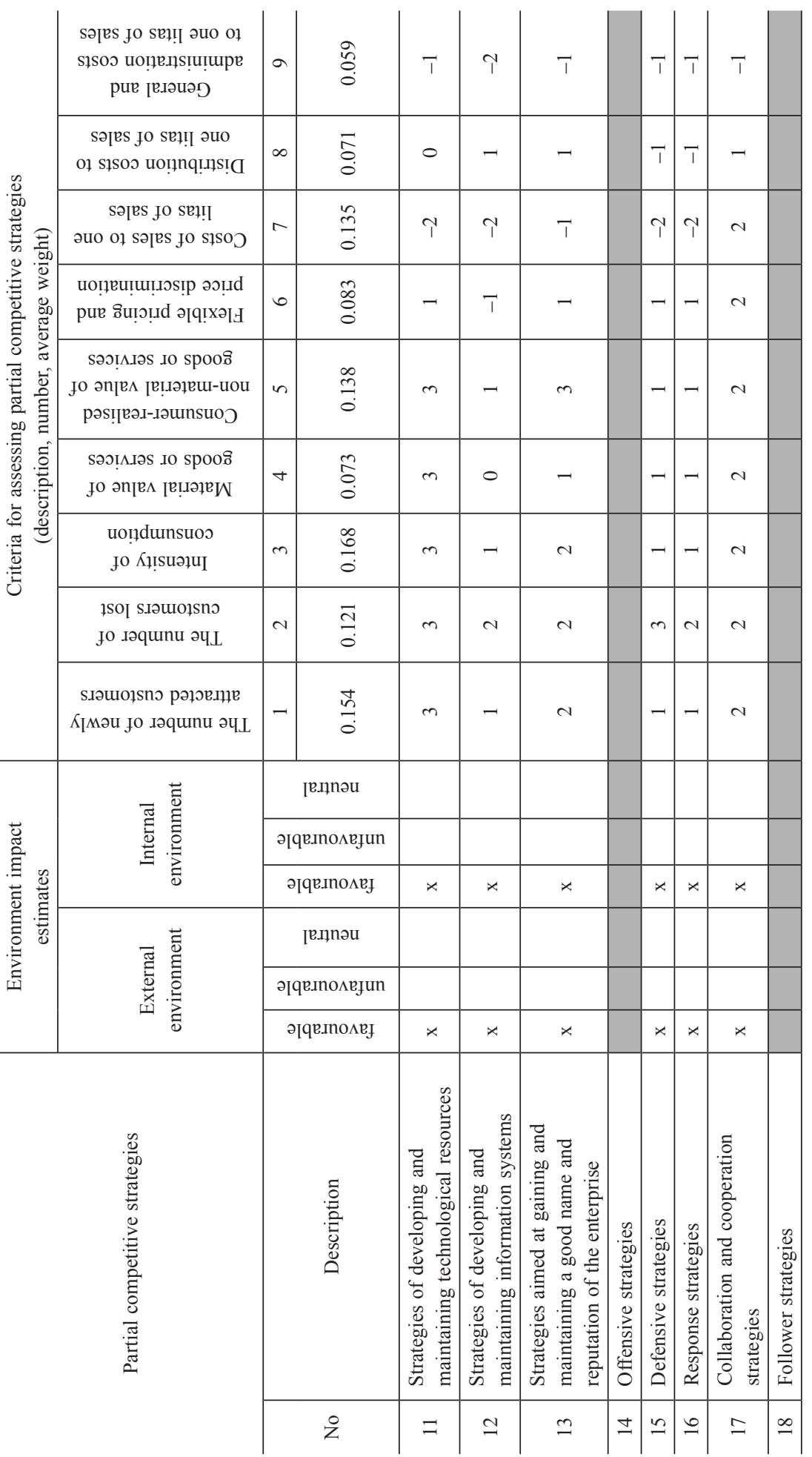




\title{
IMONĖS KONKURENCINĖS STRATEGIJOS FORMAVIMO OLIGOPOLINĖJE RINKOJE MODELIS
}

\author{
R. Ginevičius, A. Krivka, J. Šimkūnaitė
}

Santrauka

Straipsnyje skelbiamas originalus, moksliniu požiūriu naujas įmonès integruotosios konkurencinès strategijos formavimo oligopolineje rinkoje modelis ir jo empirinio pritaikymo pavyzdys. Oligopolinès įmonès integruotoji konkurencinè strategija modelyje suprantama kaip suderintas rinkinys daliniu (detaliujų) konkurencinių strategijų, nukreiptų i įmonės vidinès ir išorinės aplinkos veiksnius, turinčius itakos įmonès strateginei pozicijai ir veiklos rezultatams. Taikant modeli, atliekamas tiriamuju i̇moniu pasirinktų dalinių konkurencinių strategijų lauktino poveikio veiklos detaliesiems rodikliams kiekybinis vertinimas (pasitelkiant daugiakriterio vertinimo metodus) - palyginamas taikytinų strateginiu alternatyvų lauktinas poveikis finansiniam įmonès rezultatui, nustatant pranašiausias dalines strategijas (sudarysiančias integruotają konkurencinę strategiją) ir jų taikymo mastą (svorị integruotojoje strategijoje). Modelio pritaikymo rezultatai naudotini priimant sprendimus dèl oligopolinès įmonès konkurencinès strategijos sudarymo, skirstant finansinius, žmogiškuosius ir kitus išteklius strateginiams veiksmams formuoti ir igyvendinti.

Reikšminiai žodžiai: konkurencinè strategija, oligopolinė rinka, modelis, daugiakriteris vertinimas, SAW, TOPSIS, VIKOR.

Romualdas GINEVIČIUS. Professor, Dr Habil, Head of the Department of Enterprise Economics and Management, construction engineer and economist. The author of more than 350 research papers and over 20 scientific books; editor-in-chief of the "Journal of Business Economics and Management" (located in ISI database "Web of Science") and the journal "Business: Theory and Practice". Research interests: organization theory, complex quantitative evaluation of social processes and phenomena.

Algirdas KRIVKA. PhD student at Vilnius Gediminas Technical University (VGTU), Department of Economics and Management of Enterprises. Research interests: market structures, oligopoly, competitive strategies.

Jolita ŠIMKŪNAITE். Head of the department of Quality Management, Master of Business Management. Research interests: market concentration, quality management, organization theory. 